\title{
Implementasi Metode Promethee Dalam Sistem Pendukung Keputusan Penilaian Raport Dosen
}

\author{
Dyah Apriliani ${ }^{1 *}$, Oman Somantri ${ }^{2}$ \\ 1,2Program Studi Teknik Informatika, Politeknik Harapan Bersama, Tegal \\ 1,2 Jln Mataram No.09 Pesurungan Lor, Kota Tegal, 52142, Indonesia \\ email: 1dyah.apriliani90@gmail.com, ${ }^{2}$ oman_mantri@yahoo.com
}

Copyright $\odot 2019$, Politeknik Harapan Bersama, Tegal

\begin{abstract}
Assessment of lecturer report cards is a decisionmaking process using information obtained through measuring the results of lecturer performance by students and administrative completeness of each lecturer. The object used in this study is the Informatics Engineering IV Study Program using the Promethee method. The Promethee method is used to obtain a ranking of grades from lecturers. Promethee's method of calculating requires several alternatives and criteria. The alternative used for assessment is the lecturer who teaches in the D IV Informatics Engineering Study Program. The criteria used to assess each alternative are lecturer assessment data by students which includes student assessment input taken from the final score or the average resulting from the questionnaire assessment filled in by students. Administrative appraisal data which includes: syllabus collection, collection of college contracts, modules, number of attendance, timeliness of UTS and UAS collection questions as well as the timeliness of collecting UTS and UAS scores. From this study, the assessment of lecturer report cards was obtained, which also included lecturer rankings based on the scores produced. System testing is done by comparing result of manual assessment with results from the system. Based on the testing that has been done itt can concluded the resul of both manually and using the system are the same.
\end{abstract}

Abstrak - Penilaian raport dosen merupakan proses pengambilan keputusan dengan menngunakan informasi melalui pengukuran hasil kinerja dosen oleh mahasiswa dan kelengkapan administrasi dari masing-masing dosen. Objek yang yang digunakan dala penelitian ini adalah Program Studi D IV Teknik Informatika dengan menggunakan metode promethee. Metode Promethee digunakan untuk memperoleh perangkingan nilai dari dosen. Metode Promethee dalam melakukan perhitungan membutuhkan beberapa alternatif dan kriteria. Alternatif yang digunakan untuk penilaian yaitu dosen yang mengajar di Prodi D IV Teknik Informatika. Adapun kriteria yang digunakan untuk menilai masing-masing alternative yaitu data penilaian dosen oleh mahasiswa yang meliputi inputan penilaian mahasiswa ini diambil dari nilai akhir atau rata-rata yang dihasilkan dari penilaian questioner yang diisi oleh mahasiswa. Data penilaian administrasi yang meliputi: pengumpulan

*) Corresponding author: (Dyah Apriliani)

Email: dyah.apriliani90@gmail.com silabus, pengumpulan kontrak kuliah, modul, jumlah kehadiran, ketepatan waktu pengumpulan soal UTS dan UAS serta ketepatan waktu pengumpulan nilai UTS dan UAS. Dari penelitian ini diperoleh penilaian raport dosen yang di dalamnya juga berisi perankingan dosen berdasarkan nilai yang dihasilkan. Pengujian sistem dilakukan dengan membandingkan hasil penilaian manual dengan hasil penilaian yang dihasilkan oleh sistem. Berdasarkan pengujian yang telah dilakukan dapat disimpulkan bahwa hasil pengujian secara manual maupun menggunakan sistem adalah sama.

Kata Kunci - Sistem Pendukung Keputusan, penilaian, raport dosen, Promethee.

\section{PENDAHULUAN}

Penilaian raport dosen merupakan proses pengambilan keputusan dengan menngunakan informasi melalui pengukuran hasil kinerja dosen oleh mahasiswa dan kelengkapan administrasi. Penilaian bisa dilakukan dengan cara manual atau dengan cara menggunakan suatu sistem atau aplikasi yang khusus dibuat untuk sistem penilaian tersebut. Penilaian dengan mengunakan suatu sistem atau aplikasi akan mempermudah pihak-pihak yang berkaitan untuk menilai sesuatu dengan mudah dan hasil yang di peroleh memuaskan. Dalam sistem penilaian kinerja ini terdapat beberapa parameter penilaiannya dan sistemnya dibuat dengan cara admin menginputkan nilai parameter dosen dan sistem atau aplikasi tersebuat akan memproses sehingga mendapatkan nilai dan nilai tersebut akan dirankingkan. Proses perankingan aplikasi ini menggunakan metode Pomethee.

Preference rangking Organization Method for Enrichment Evaluation (Promethee) merupakan salah satu metode daam sistem pendukung keputusan yang bersifat multi criteria decision making (MCDM). Metode Promethee merupakan metode yang mampu melakukan perhitungan untuk melakukan penentuan urutan (prioritas) dalam sistem pendukung keputusan terutama untuk masalah MCDM. Metode Promethee adalah metode yang sederhana, jelas dan stabil. Dalam metode Promethee dibutuhkan beberapa parameter, dimana parameter yang digunakan tersebut mempunyai pengaruh nyata terhadap permasalahan yang akan diselesaikan. Metode Promethee merupakan sebuah metode yang digunakan dalam sistem pendukung keputusan yang 
mampu menetukan urutan prioritas dalam analisis multikriteria yang memberikan penawaran yang fleksibel dan sederhana kepada user yang akan membuat keputusan. Metode Promethee dapat digunakan untuk melakukan analisis masalah multikriteria yang menggunakan prinsip outrangking. Metode ini, bertujuan untuk memudahkan proses pengambilan keputusan terhadap alternatif yang ada dengan melalukan pengolahan terhadap kriteria permasalahan. Metode promethee mengelompokkan tipe keputusan menjadi enam fungsi kriteria (perferensi), yaitu usual criterion, quasi criterion, linear criterion, level criterion, kriteria linier dan area yang tidak berbeda, dan gaussion criterion [1].

Sebuah kegiatan penilaian kinerja dosen yang dilakukan di Prodi D IV Teknik Informatika setiap akhir semester masih menggunakan cara manual, dengan cara mengumpulkan data dan mencatat dengan cara manual serta melakukan perhitungan dengan cara manual. Tetapi cara yang dilakukan tersebut proses pengolahan rapot dosen memerlukan waktu yang lama. Oleh karena itu, dibutuhkan sistem penilaian rapot dosen dengan menggunakan metode Promethee sehingga penilaian rapot dosen dapat berjalan secara cepat dan tepat Dengan adanya sistem tersebut diharapkam lebih mempermudah dalam memantau kinerja dosen, sehingga dapat memberikan tindakan selanjutnya sehingga dapat meningkatakan kualitas kinerja dosen yang ada. Berdasarkan uraian diatas, maka akan dibuat sebuah Sistem Penilaian Raport Dosen Menggunakan metode Promethee study kasus Program Studi D IV Teknik Informatika. Sistem yang dibuat ini akan dikelola oleh Koordinator Penjamin Mutu di Prodi D IV Teknik Informatika sehingga menghasilkan sebuah raport dosen yang nantinya akan dibagikan pada saat yudisium nilai.

Tujuan dari penelitian yang dilakukan ini adalah menghasilkan sebuah sistem berbasis website yang dapat digunakan dalam propes penilaian rapot dosen di Program Studi D IV Teknik Informatika yang mampu menghasilkan perangkingan dosen secara lebih efektif dan efisien dengan menggunakan Promethee.

\section{PENELITIAN YANG TERKAIT}

Penelitian terkait dengan penerapan Analitycal Hierarchy Procces (AHP) dalam sistem pendukung keputusan penilaian kinerja Guru (Studi Kasus SD Negeri 095224). Penelitian dilakukan untuk menghasikan keputusan dengan memberikan nilai persepsi sebagai pembobot oleh seorang pengambil keputusan atau ahli. Penerapannya dilakukan dengan memperhatikan tiga unsur penting dan mutlak dalam pelaksanaan penilaian. Guru merupakan orang yang mengajar di sebuah sekolah, baik dari semua tingkatan yang ada di tingkat pembelajran formal. Perkembangan teknologi yang ada menyebabkan beberpa factor diantaranya kesulitan dalam menggunakan teknologi untuk menyelesaikan permasalahan. Terutama dalam proses penilaian kinerja guru. Dengan permasalahan tersebut maka dilakukan pembuatan sistem dengan menggunakan metode AHP yang dirasakan mampu mempermudah dalam menyelesaikan permasalahan penilaian kinerja guru tersebut. AHP merupakan sebuah kegiatan untuk menemukan dan mengembangkan berbagai alternatif tindakan yang mungkin untuk dilakukan.Penilaian kinerja guru dengan metode AHP dapat mempermudah pengambil keputusan untuk melakukan penilaian kinerga guru secara lebih baik dan optimal [2].
Penelitian lain terkait dengan sistem pendukung keputusan penilaian kinerja pegawai menggunakan metode Promethee. Penelitian tersebut bahwa sumber daya manusia (SDM) merupakan salah satu faktor yang menentukan keberhasilan sebuah organisasi maupun perusahaan. Proses penilaian karyawan ini dilakukan sebagai pertimbangan untuk kenaikan pangkat dari pegawainya. Proses penilaian kinerja pegawai dengan mnggunakan cara yang manual sering mengalami kesulitan. Hasil yang diperolehpun belum sepenuhnya terbuka sesuai dengan kinerjanya, malainkan ada unsure subjektifitas. Untuk mengatasi permasalahan tersebut maka dibutuhkan sebuah sistem pendukung keputusan yang dapat melakukan penilaian terhadap kinerja pegawai. Sistem pendukung keputusan untuk penilaian kinerja ini didasarkan pada data pegawai yang ada di Museum Ranggawarsita Semarang. Proses penilaian di sistem dilakukan dengan mengimplementasikan metode Promethee. Beberapa kriteria yang digunakan dalam penilaian ini meliputi penilaian DP3, masa kerja, tingkat prndidikan dan golongan. Hasil yang diperoleh dari perhitungan dengan sistem ini akan membantu penilai dalam mengevaluasi pegawai dan juga menentukan kenaikan pangkat dari pegawai yang ada [3]

Penelitian Vinodh dkk, (2012) menyatakan bahwa organisasi manufaktur mulai mengakui pentingnya konsep keberlanjutan. Hal itu disebabkan meningkatnya peraturan pemerintah dan kesadaran produk yang berkelanjutan antara pelanggan. Secara umum, konsep keberlanjutan diklasifikasikan ke dalam perspektif ekonomi, lingkungan dan sosial. Klasifikasi konsep berkelanjutan mengenai perusahaan-perusahaan manufaktur dapat berupa materi yang digunakan, desain produk dan proses manufaktur. Pemilihan konsep berkelanjutan adalah masalah penting bagi organisasi manufaktur kontemporer. Penelitian ini menggunakan metode Preference Ranking Organisational Method for Enrichment Evaluation (Promethee) yang termasuk dalam Multi Criteria Decision making (MCDM). Metode ini digunakan karena proses seleksi pemilihan konsep berkelanjutan yang terbaik dilakukan dengan menggunakan beberapa kriteria (perspektif) yang telah ditentukan, yaitu: perspektif ekonomi, lingkungan dan sosial [4].

Dalam penelitian Alp dkk, (2011) Metode Promethee merupakan metode MCDC yang sering digunakan untuk perangkingan terhadap suatu alternatif tertentu. Metode ini sering digunakan dalam berbagai kasus penelitian diantarnya digunakan untuk menyelesaikan kasus pemilihan lokasi. Berikut ini adalah beberapa penelitian untuk menentukan lokasi, diantaranya adalah penentuan lokasi garasi bis menggunakan metode fuzzy AHP dan Promethee. Dalam penelitian tersebut metode Promethee digunakan untuk melakukan perangkingan untuk menentukan lokasi garasi bis. Pembukaan lokasi ini disesuaikan dengan kebutuhan transportasi, pertumbuhan penduduk, dan lahan yang akan digunakan untuk lokasi tersebut [5].

Penelitian lain mengunakan metode Promethee dilakukan oleh Tomic dkk., (2013) metode Promethee digunakan untuk menentukan lokasi yang paling untuk pusat gudang logistik. Dalam penelitian ini hanya menggunakan metode Promethee, metode tersebut digunakan untuk melakukan perangkingan lokasi terbaik yang akan dijadikan sebagai lokasi pusat gudang logistik [6]. 
Berbeda dengan beberapa penelitian yang telah disebutkan, pada penelitian ini metode promethee diterapkan dalam pembuatan sebuah pendukung keputusan dalam menilai kinerja dosen yang berdasarkn pada hasi penilaian rapot penilaian dosen tersebut sehingga mejadikannya sebagai pendukung keputusan untuk menentukan sistem kinerja dosen yang bersangkutan.

\section{PROMETHEE}

\section{A. Metode Promethee}

Metode Promethee merupakan sebuah metode yang dipakai untuk menentukan urutan atau prioritas penilaian dengan multikriteria. Metode ini digunakan karena dengan metode ini mampu menghasilkan sebuah perhitungan yang fleksibel dan sederhana kepada pembuat keputusan. Metode Promethee dibuat untuk melakukan penilaian terhadap permasalahan permasalahan multikriteria [7]. Metode Promethee merupakan metode yang menggunakan prinsip outranking dalam penentuan penilaian [8]. Tujuan metode ini adalah untuk memberikan kemudahan pengambil keputusan dalam menetukan urutan prioritas, dengan mengelompokkan tipe keputusan kedalam wnam fungsi preferensi (kriteria). Beberapa fungsi preferensi dalam metode Promethee adalah sebagai berikut [9]:

\section{1) Kriteria Biasa}

Kriteria biasa digunakan untuk permasalahan dimana masing-masing alternatif memiliki nilai kriteria yang berbeda. Dengan menggunakan preferensi ini pembuat keputusan dapat memberikan preferensi mutlak untuk sebuah alternatif yang memiliki nilai yang lebih baik. Apabila nilai dari masingmasing alternative sama penting maka tidak ada perbedaan nilai antara kedua alternatif Berikut ini adalah persamaan yang digunakan dalam kriteria biasa.

$$
p(x)=\left\{\begin{array}{l}
0 \text { jika } \forall x \leq 0 \\
1 \text { jika } \forall x>1
\end{array}\right.
$$

$$
\text { Dimana, } x=f(a)-f(b) \text { ) }
$$

\section{2) Kriteria Quasi (Quasi Criterion)}

Kriteria ini digunakan ketika alternatif memiliki preferensi yang sama penting untuk sebuah kriteria tertentu, yang nilaianya tidak lebih dari batas nilai $l$. Berikut ini adalah persamaan yang dipakai untuk melakukan perhitungan dengan menggunakan kriteria quasi.

$$
\begin{aligned}
& p(x)=\left\{\begin{array}{l}
0 \text { jika } x \leq l \\
1 \text { jika } x>l
\end{array}\right. \\
& \text { Dimana, } x=f(a)-f(b)
\end{aligned}
$$

\section{3) Kriteria dengan preferensi Linear}

Kriteria dengan menggunakan preferensi linear dihitung selama nilai selisih yang dihasilkan lebih rendah dari nilai $x$, sehingga preferensi meningkat secara linear dengan nilai $m$. Jika $X$ lebih besar dari $m$, maka nilai preferensinya menjadi mutlak. Berikut ini adalah persamaan yang digunakan untuk menghitung kriteria linear.

$$
p(x)=\left\{\begin{array}{c}
x / m \text { jika } x \leq m \\
1 \text { jika } x>m
\end{array}\right.
$$

$$
\text { Dimana, } x=f(a)-f(b)
$$

\section{4) Kriteria Level}

Kriteria Level digunakan ketika nilai $x$, berasa diantara nilai $\mathrm{p}$ dan $\mathrm{q}$, maka nilai $\mathrm{p}(x)=0,5$, Berikut ini adalah persamaan untuk menghitung kriteria level.

$$
\begin{aligned}
& p(x)=\left\{\begin{array}{c}
0 \text { jika } x \leq q \\
1 / 2, \text { jika } q<x \leq q+p \\
1 \text { jika } x>q+p
\end{array}\right. \\
& \text { Dimana, } x=f(a)-f(b)
\end{aligned}
$$

5) Kriteria Preferensi linear dan area yang tidak berbeda.

Pada umumnya pembuat keputusan mempertimbangkan peningkatan preferensi secara linear dan tidak berbeda, sehingga nilai preferensi mutlak yang dihasilkan merada dalam area terntutu yang memiliki dua kecenderungan yaitu $s$ dan $r$. Berikut ini adalah persaman yang digunakan dalam tipe preferensi ini.

$$
\begin{gathered}
p(x)=\left\{\begin{array}{c}
0 \text { jika } x \leq s \\
(x-s) / r \text { jika } s<x \leq s+r \\
1 \text { jika } x<s+r
\end{array}\right. \\
\text { Dimana, } x=f(a)-f(b)
\end{gathered}
$$

\section{6) Kriteria Gaussian}

Kriteria ini digunakan untuk mencari nilai aman yang berjalan terus-menerus. Dalam tipe preferensi ini telah ditentukan semuah nilai yaitu $\sigma$. Berikut ini adalah persamaannya.

$$
p(x)=\left\{\begin{array}{c}
0 \text { jika } x \leq 0 \\
1-e^{-x^{2} / 2 \sigma^{2}} \text { jika } x>0
\end{array}\right.
$$

$$
\text { Dimana, } x=f(a)-f(b)
$$

Metode Promethee yang digunakan dalam penelitian ini memiliki kelebihan, di antaranya metode ini memiliki fungsi preferensi yang digunakan untuk mengelompokkan tipe keputusan. Salah satu tipe tersebut adalah tipe preferensi linear. Tipe ini memiliki kelebihan dibandingkan dengan tipe yang lain. Tipe ini mampu mengatasi selisih yang sangat kecil antar kriteria yang dimiliki oleh alternatif yang akan dinilai. Sehingga ketika nilai perbandingan antar kriterian kecil tetapi masih terlihat perbedaannya. 


\section{METODE PENELITIAN}

\section{A. Alur Penelitian}

Kerangka penelitian dari implementasi sistem pendukung keputusan penilaian raport dosen program studi D IV Teknik Informatika dilakukan dengan melakukan beberapa tahapan seperti yang terlihat pada Gbr 1 .

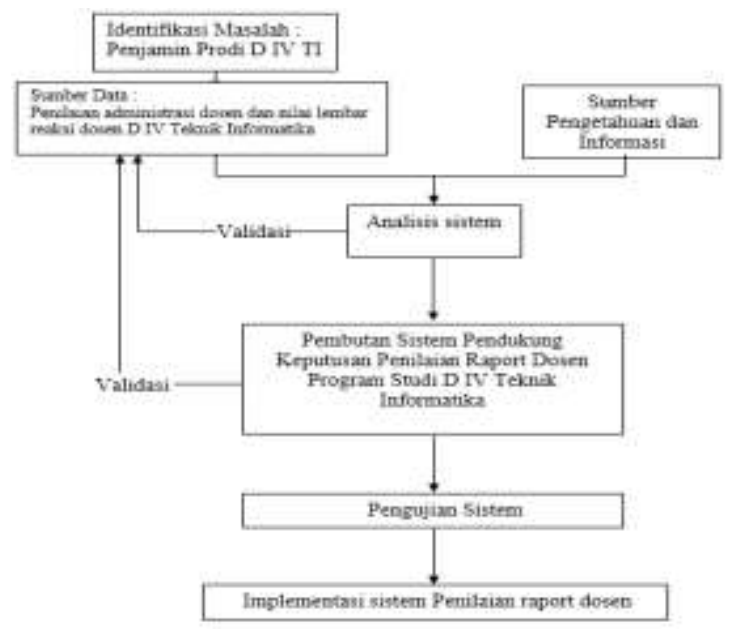

Gbr.1 Kerangka Penelitian implementasi Sistem Penilaian Raport Dosen

Pada Gbr.1 dapat dijelaskan alur dan tahapan yang telah dilakukan pada penelitian ini.

a) Identifikasi masalah: peneliti mengidentifikasi permasalahan mengenai proses penilaian raport dosen yang saat ini berjalan.

b) Pengumpulan data: peniliti mengumpulkan data dari sumber data serta sumber pengetahuan dan informasi yang dapat dijadikan acuan sekaligus mengakuisisi pengetahuan seorang narasumber yang dapat dijadikan sumber pengetahuan dan sumber informasi utama dalampembuatan system ini.

c) Analisis Sistem: Data dan sumber pengetahuan yang telah direpresentasikan, kemudian dianalisis untuk dijadikan acuan utama, kemudian setiap data akan divalidasi oleh seorang narasumber yang dijadikan sumber pengetahuan .

d) Pembuatan sisitem: Data yang telah selesai dianalisis, kemudian direpresentasikan kedalam sebuah bahasa yang dapat dipahami oleh komputer menggunakan bahasa pemrograman tertentu.

e) Pengujian Sistem: Hasil representasi bahasa komputer yang telah dibuat dilakukan uji coba sebelum digunakan.

\section{B. Alat dan Bahan Penelitian}

Data penelitian yng digunakan pada penelitian ini dalah data penilaian raport dosen, yang meliputi hasil analisis lembar reaksi mahasiswa, ketepatan pengumpulan RPS, kontrak kuliah, pengumpulan materi kuliah, kehadiran dosen, kelengkapan jurnal perkuliahan, ketepatan waktu pengumpulan soal UTS, pengumpulan soal UAS, pengumpulan nilai UTS dan pengumpulan nilai UAS pada program studi Teknik Informatika Politeknik harapan Bersama Tegal. Sebagai data alternatif yang digunakan untuk melakukan penelitian ini meliputi data dosen yang mengajar pda prodi D IV TI beserta data nilai yang digunakan dalam penilaian dosen semester genap TA 2017/2018.

\section{HASIL DAN PEMBAHASAN}

A. User Interface

Aplikasi diimplementasikan dengan menggunakan bahasa pemrograman PHP dengan framework CI dan dengan menggunakan My SQL sebagai databasenya. Berikut ini adalah tampilan awal yang muncul ketika admin login adalah тепи home, seperti yang terlihat dalam Gbr 2 .

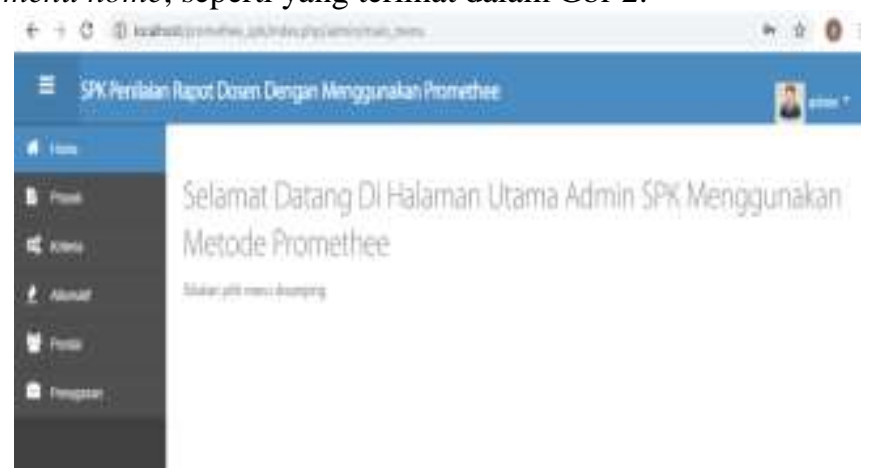

Gbr. 2 Tampilan menu admin

Dalam menu yang ada dalam tampilan aplikasi diantaranya adalah menu Kriteria. Menu kriteria digunakan oleh admin untuk menambah, mengubah, maupun menghapus kreteria yang akan dijadikan penilaian. Berarti disini ditambahkan data tentang komponen penilaian raport dosen. Pada Gbr 3 dapat dilihat tampilan menu kriteria.

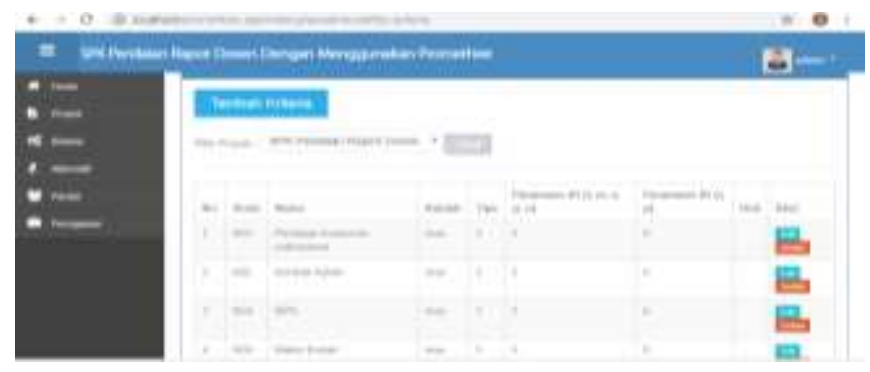

Gbr. 3 Tampilan Menu Kriteria

Halaman selanjutnya adalah halaman beri nilai proyek yang akan digunakan oleh penilai untuk memberikan penilaian terhadap masing-masing alternative yang ada. Halam ini yang nantinya akan diproses untuk menghasilkan perhitungan dengan menggunakan metode Promethee. Preferensi yang digunakan dalam penilaian ini adalah preferensi linear. Pada gbr 4 adalah tampilan proses penilaian yang dilakukan.

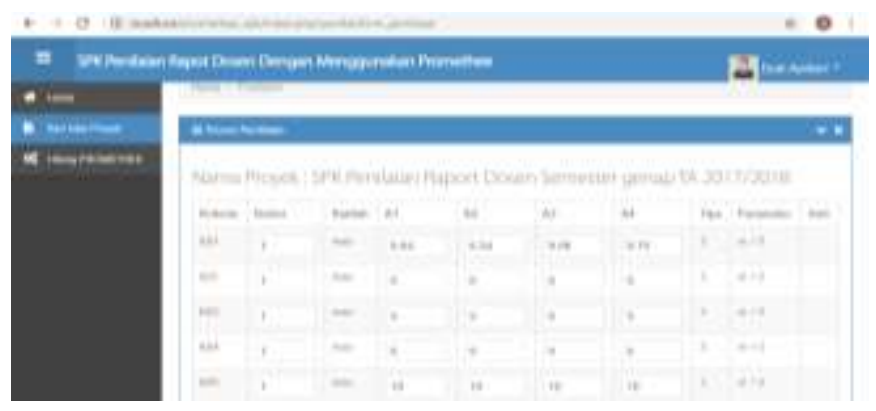

Gbr. 4 Tampilan Halaman Penilian Beri Nilai Proyek 
Halaman hitung Promethee digunakan penilai untuk memberikan perangkingan penilaian raport dosen. Pada menu ini akan diperoleh nilai ranking masing-masing dosen. Promethee mengolah nilai yang telah diinputkan sebelumnya. Berikut ini adalah tampilan hasil penilaian pada Gbr. 5.

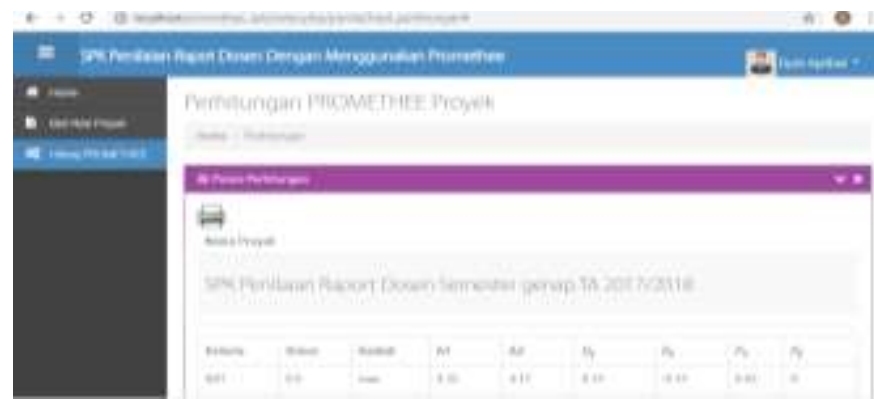

Gbr 5. Tampilan Halaman Penilai Hitung Promethee

\section{B. Uji Sistem}

Pengujian sistem dilakukan dengan melakukan uji coba terhadap menu yang ada. Hasil penilaian menunjukkan sistem dapat berjalan sesuai dengan perencanaan yang telah dibuat. Selain itu pengujian dilakukan dengan melakukan pengecekan perangkingan manual dengan penilian yang dihasilkan oleh sistem. Dari hasil pengecekan baik yang manual maupun tersistem menghasilkan hasil perangkingan yang sama.

\section{KESIMPULAN}

Hasil penelitian dengan pembangunan aplikasi sistem pendukung keputusan ini dapat digunakan sebagai media untuk melakukan penilaian raport dosen prodi D IV Teknik Informatika. Aplikasi hasil penelitian dapat digunakan sebagai media untuk mempercepat proses penilaian raport dosen dan mampu melakukan perankingan dengan menggunakan pembobotan yang terhadap kriteria yang dapat disesuaikan sehingga lebih fleksibel.

\section{UCAPAN TERIMA KASIH}

Terima kasih kami ucapkan kepada Pusat Penelitian dan Pengabdian Kepada Masyarakat Politeknik Harapan Bersama Tegal yang telah membiayai penelitian ini tahun anggaran 2018.

\section{DAFTAR PUSTAKA}

[1] J. P. Brans and P. Vincke, "Note-A Preference Ranking Organisation Method," Manage. Sci., vol. 31, no. 6, pp. 647-656, Jun. 1985.

[2] R. Artika, "Penerapan Analitycal Hierarchy Proccces(AHP) Dalam Pendukung Keputusan Penilaian Kinerja Guru Pada SD Negeri 095224," Pelita Inform. Inf. dan Inform., vol. 4, no. 3, Aug. 2013.

[3] A. W.C.Dwiyanto, "Sistem Pendukung Keputusan Penilaian Kinerja Pegawai Menggunakan Metode Promethee Di Museum Ranggawarsita Semarang," Universitas Dian Nuswantoro, 2012.

[4] S. Vinodh and R. Jeya Girubha, "PROMETHEE based sustainable concept selection," Appl. Math. Model., vol. 36, no. 11, pp. 53015308, Nov. 2012.

[5] Ö. N. Alp, N. Demirtaș, H. Baraçli, and U. R. Tuzkaya, "Fuzzy AhpPromethee Methodology To Select Bus Garage Location: A Case Study For A Firm In The Urban Passenger Transport Sector In Istanbul," in 15th International Research/Expert Conference, 2011.

[6] V. Tomić, A. Memet, M. Milosavljević, And S. Milisavljević, "Decisions On The Logistic Centers Location, Case Of The Balkan Peninsula," Ann. ORADEA Univ. Fascicle Manag. Technol. Eng., vol. XXII (XII), no. 2, 2013.

[7] M. J. Raymond and J. Eleanor, Systems development: a project management approach. Wiley, 2001.

[8] E. K. Kenneth and E. K. Julie, Analisis dan Perancangan Sistem. 2018.

[9] D. Apriliani, K. Adi, and R. Gernowo, "Implementasi Metode Promethee Dan Borda Dalam Sistem Pendukung Keputusan Pemilihan Lokasi Pembukaan Cabang Baru Bank," J. Sist. Inf. BISNIS, vol. 5, no. 2, pp. $145-150$, Oct. 2015 